\title{
Pelaksanaan Wakaf Produktif di Bank Wakaf Mikro Syariah Denanyar Jombang
}

\author{
Maulana Assegaf \\ UIN Sunan Ampel Surabaya \\ maulanaasegaf23@gmail.com \\ Khairul Mursyid \\ UIN Sunan Ampel Surabaya \\ bapangjaya@gmail.com
}

\begin{abstract}
Abstrak
Penelitian ini bermaksud mengungkap praktik atau model pelaksanaan wakaf produktif yang dilakukan oleh Bank Wakaf Mikro Syariah di Jombang, Jawa Timur. Model pelaksaan wakaf produktif sangat jarang ditemukan di lembaga lain, dan bahkan nyaris tidak ada. Selain itu, model tersebut dapat menjawab kegelisahan para pelaksana di lembaga perkawakafan terkait dengan strategi yang tak kunjung menemukan formasi tepat. Signifikansi penelitian ini terletak pada model pemberdayaan dan pemberian modal usaha sebagai pentuk wakaf produktif kepada beberapa UMKM potensial. Model ini menjadi pembeda dengan beberapa lembaga wakaf. Metode yang digunakan adalah metode kualitatif deskriptif, dari hasil wawancara data diperoleh dari pimpinan atau staff yang terkait, serta didukung dengan studi dokumentasi yang dapat membantu keakuratan informasi yang dibutuhkan oleh peneliti, diantaranya struktur organisasi dan standart oprasional. Sehingga menghasilkan beberapa temuan, yaitu dalam program tahap awal dalam Bank Wakaf Mikro adalah "Pemberdayaan Masyarakat melalu Pendirian LKM Syariah sekitar Pesantren" yang diprakarsai oleh Lembaga Amil Zakat Nasional Bank Wakaf Mandiri (LAZNAS BSM) yang mana pendiriannya difasilitasi oleh Otoritas Jasa Keuangan (OJK) dan Pusat Inkubasi Bisnis Usaha Kecil (Pinbuk). Proses pelaksanaan wakaf produktif di Bank Wakaf Mikro Denanyar, menggunakan sistem penyalurannya dengan produktif, disalurkannya kepada nasabah yang punya usaha untuk mengembangkan usaha nashabah yang mana cara penyalurannya itu dengan sysitem Kelompok Usaha Masyarakat Sekitar Pesantren Indonesia (KUMPI).
\end{abstract}

Keyword: Wakaf, Produktivitas, Bank Wakaf Mikro

\section{Latar Belakang}

Beberapa tahun terakhir, wacana pengembangan wakaf secara produktif di Indonesia cukup massif, baik dari kalangan masyarakat maupun pemerintah. Hal ini dapat dimaklumi karena prinsip dari ajaran 
wakaf itu sendiri berbasis pada upaya optimalisasi peran kelembagaan Islam untuk peningkatan kesejahteraan masyarakat.

Definisi wakaf mengalami pergeseran ke arah yang lebih fleksibel dan menguntungkan, yakni bahwa wakaf diartikan sebagai perbuatan hukum wakif untuk memisahkan dan/atau menyerahkan sebagian harta benda miliknya untuk dimanfaatkan selamanya atau untuk jangka waktu tertetu sesuai dengan kepentingannya guna keperluan ibadah da/atau kesejahteraan umum menurut syariah. ${ }^{1}$ Perkembangan yang perlu digarisbahi ialah kemungkinannya melakukan wakaf untuk jangka waktu tertentu, misalnya satu atau dua tahun dan tidak mesti untuk muaabbad atau selamanya sebagaimana yang lazin dipahami pada waktu yang lalu. ${ }^{2}$

Harus diakui, berbagai upaya pengelolaan wakaf secara produktif telah dilakukan, baik dari organisasi Islam, nazhir, perguruan tinggi, LSM, maupun pemerintah sendiri. ${ }^{3}$ Lahirnya Undang-Undang Nomor 41 tahun 2004 tentang Wakaf dan Peraturan Pemerintah Nomor 42 Tahun 2006 tentang Pelaksanaannya merupakan bukti bahwa pemerintah menggarap wakaf secara serius sebagai payung hukum untuk mengembangkan perwakafan di masa mendatang. Bahkan upaya pemerintah meregulasi peraturan terkait dengan masalah tersebut masih terus dilakukan yang bertujuan memberdayakan lembaga-lembaga keagamaan secara optimal untuk kepentingan peningkatan kesejahteraan masyarakat banyak.

Jika mencermati kekayaan wakaf yang kita miliki, khususnya wakaf tanah yang memiliki luas lebih dari 2,7 milyar meter persegi, ${ }^{4}$ sebenarnya kita dapat memberdayakannya secara lebih optimal. Jumlah tanah wakaf yang apabila dikumpulkan menjadi satu melebihi luasnya kota Jakarta merupakan potensi yang sungguh sangat besar. Tentu, tidak semua tanah wakaf harus dikelola secara produktif, dalam arti harus menghasilkan uang, tetapi setidaknya dari jumlah tersebut sekitar 10 persen dapat dikelola secara produktif.

\footnotetext{
${ }^{1}$ Abu Azam al-Hadi, Upaya Pemberdayaan Tanah Wakaf Produktif bagi Kesejahteraan Ummat. ISLAMICA, 4 (1) 2009, hlm. 98.

${ }^{2}$ Wawan Hermawan, Politik Hukum Wakaf di Indonesia. Ta'lim: Jurnal Pendidikan Islam, 12 (2) 2014, hlm. 148.

${ }^{3}$ Fahruddin Ali Sabri, Wakaf Uang (Sebuah Alternatif dalam Upaya Menejahterakan Masyarakat). Al-Ihkam, 8 (1) 2013, hlm. 42

${ }^{4}$ https://money.kompas.com/read/2019/09/27/201410426/potensi-besar-wakaf-produktifbelum-tersosialisasi-dengan-baik diakses tanggal 09 Juni 2019.
} 
Maulana Assegaf. Pelaksanaan Wakaf Produktif Di Bank Wakaf Mikro...

Oleh karena itu, upaya pengembangan wakaf harus dilakukan dengan pola yang integratif dan terencana dengan baik, sehingga wakaf dapat dikelola secara optimal dan memberi manfaat yang lebih luas bagi kepentingan sosial. Dengan demikian yang dikelola secara produktif ekan menjadi salah satu pilar yang perlu diperhitungkan dalam mengatasi keterpurukan ekonomi masyarakat dana jalan alternatif pengentasan kemiskinan. ${ }^{5}$

Wakaf atau perwakafan merupakan pranata dalam agama Islam yang sudah mapan. Di dalam hukum Islam, wakaf tersebut termasuk ke dalam kategori ibadah kemasyarakatan. ${ }^{6}$ Sepanjang sejarah Islam, wakaf merupakan sarana dan modal yang amat penting dalam memajukan perkembangan agama. Khususnya perkawafakan tana di Indonesia. Ditinjau dari sudut perundang-undangan nomor 5 tahun 1960 tentang peraturan dasar pokok Agraria sangatlah penting, sehingga perlu diatur dalam peraturan pemerintah yaitu PP nomor 28 tahun 1977 tentang perwakafan tanah milik, sehingga tanah wakaf dapaat digunakan sebagai salah satu sarana pengembangan kehidupan keagamaan dan kemasyarakat, khususnya bagi umat Islam dalam rangka mencapai kesejahteraan materiil dan spiritual menuju masyarakat adil dan makmur. ${ }^{7}$

Berdasarkan data yang ada dalam masyarakat, pada umumnya wakaf di Indonesia digunakan untuk masjid, musholla, sekolah, ponpes, rumah yatim piatu dan makam, sedikit sekali tanah wakaf yang dikelola secara produktif dalam bentuk suatu usaha yang hasilnya dapat dimanfaatkan bagi pihak-pihak yang memerlukan, khususnya kaum fakir miskin. ${ }^{8}$ Pemanfaatan tersebut dilihat dari segi sosial khususnya untuk kepentingan pribadatan memang efektif, tetapi dampaknya kurang brpengaruh positif dalam kehidupan ekonomi masyarakat. Apabila peruntukan wakaf hanyai terbatas pada hal-hal diatas tanpa dimbangi dengan wakaf yang dikelola secara produktif, maka kesejahteraan sosial ekonomi masyarakat yang diharapkan

\footnotetext{
${ }^{5}$ Akhmad Sirojudin Munir, Optimalisasi Pemberdayaan Wakaf Secara Produktif. Jurnal Ummul Qura, IV (2) 2015, hlm. 96.

${ }^{6}$ Asmak Ab Rahman, Peranan Wakaf dalam Pembangunan Ekonomi Umat Islam dan Aplikasinya di Malaysia. Jurnal Syairiah, 17 (1) 2009, hlm. 118.

${ }^{7}$ Departemen Agama, Perkembangan Pengegeloaan Wakaf di Indonesia (Jakarta: Direktorat Jenderal Bimbingan Masyarakat Islam dan Penyelenggaraan Haji, 2003), 1

8 Ahmad Furqon, Model-Model Pembiayaan Wakaf Tanah Produktif. ECONOMICA, V (1) 2014, hlm. 5 .
} 
dari lembagai wakaf, itidak akan dapat terealisisasi secara optimal. Wakaf bisa juga dijadikan sebagai lembaga ekonomi yang potensial untuk dikembangkan selama bisa dikelola secara optimal. Karena institusi perwakafan merupakan salah satu asset kebudayaan nasioanal dari aspek social yang perlu mendapat perhatian sebagai penopang hidup dan harga diri bangsa. ${ }^{9}$

\section{Kajian Pustaka}

Peran manajemen dalam perwakafan sangat diperlukan untuk mengatur atau mengontrol jalannya pengelolaan harta wakaf, penghimpunan wakaf uang, dan untuk menjaga hubungan antara nazir, waqif, serta masyarakat. Supaya kesemuanya dapat berjalan dengan baik, maka seorang nadzir harus dapat menguasai prinsip-prinsip manajemen meliputi: ${ }^{10}$

1. Tahap fungsi manajemen, yang didalamnya terdapat empat aspek manajemen yang harus dikuasai nadzir, yaitu perencanaan, pengorganisasian, pengarahan, dan pengawasan

2. Manajemen Fundraising. Penyusunan strategi dan rencana program kerja dalam wakaf produktif harus rinci dengan perumusan yang spesifik.

3. Manajemen pengembangan. Untuk menekan resiko bisnis, pengembangan asset wakaf menjadi alternatifnya. Menurut Abdurrahman, ${ }^{11}$ terdapat lima pengembangan strategi dalam pendanaan wakaf secara tradisonal, yaitu 1) Dengan meminjamkan wakaf, 2) Dengan menjual hak monopoli wakaf, 3) Menyewakan asset wakaf dalam kurun waktu tertentu, dengan pembayaran cash, pembayaran berkala, atau keduanya, 3) Menambah wakaf baru ke wakaf lama yang sejenis, 4) Dengan menukar harta wakaf. Selain itu, Abdurrahman juga menyebutkan strategi pendanaan modern yang sejalan dengan pengembangan harta wakaf dari segi memperoleh dana, yaitu 1) Sistem bagi hasil untuk mendapatkan keuntungan yang jelas atau disebut dengan murabahah, 2) strategi pendanaan dengan jalan kerja sama antara

\footnotetext{
${ }^{9} \mathrm{Ibid} ., 5$

${ }^{10}$ Nailis Sa'adah, Fariq Wahyudi, Manajemen Wakaf Produktif: Studi Analisis pada Baitul Mal di Kabupaten Kudus, Equilibrium : Jurnal Ekonomi Syari'ah Vol 4, Nomor 2, 2016, 337

${ }^{11}$ Ibid.,137
} 
Maulana Assegaf. Pelaksanaan Wakaf Produktif Di Bank Wakaf Mikro...

nadzir dan investor, 3) Pendirian perusahaan milik gabungan (syirkah milk), 4) Penggalangan dana dari public.

4. Manajemen Pemanfaatan. Pendistribusian menurut sistem ekonomi Islam haruslah berdasar pada dua sendi yaitu, kebebasan dalam bertindak sesuai dengan nilai-nilai agama, serta keadilan dalam kepemilikan.

5. Manajemen Pelaporan. Laporan keuangan merupakan refleksi dari beberapa transaksi dalam perusahaan.

\section{Metode Penelitian}

Jenis penelitian yang digunkan adalah metode kualitatif deskriptif pada Bank Wakaf Mikro Syariah Denanyar Jombang, tujuan dari metode penelitian ini peneliti ingin memberikan gambaran bagaimana Proses pelaksanaan wakaf produktif serta manajemen pengelolaan dan cara merekrut nashabah di Bank Wakaf Mikro Denanyar Jombang.

Dari hasil wawancara data diperoleh dari pimpinan atau staff yang terkait, serta didukung dengan studi dokumentasi yang dapat membantu keakuratan informasi yang dibutuhkan oleh peneliti. Jenis data yang digunakan dalam penelitian ini jenis data subjektif jenis subjektif berupa opine narasumber yang mana informasi didapat melalui hasil wawancara dengan pengambilan sampel sumber data secara purposive sampling. ${ }^{12}$ sehingga wawancara akan dilakukan kepada pimpinan dan staffnya, diantaranya staff yang dituju adalah bagian Administrasi dan Supervisor. Data dokumentasi yang peneliti butuhkan diantaranya terkait struktur organisasi dan Standart Operasional Prosedur (SOP) pengelolaan.

Pengumpulan data pada penelitian ini menggunakan data wawancara yang mana ditujukan kepada narasumber yang bersangkutan. Teknik pengumpuan data yang akan peneliti gunakan adalah wawancara semi terstruktur. Wawancara semi terstruktur pada peneliti ini sudah disiapkan oleh peneliti pada nara sumber. Data yang sudah disiapkan peneliti diantaranya adalah, perencanan, pengelolaan, perkembangan, pemanfaatan, serta prosedur pendaftaran nasabah.

\footnotetext{
${ }^{12}$ Sugiyono, Metodologi Penelitian Kuantitatif, Kualitatif dan RED, (Bandung: Alfabeta, 2013), 218
} 
Teknik Pengolahan Data setelah pengumpulan data sudah dilakukan maka data yang sudah diperoleh kemudian diolah. Cara yang dilakukan adalah hasil data wawancara dan dokumentasi dianaisis apakah sesuai dengan teori wakaf produktif. Untuk memeriksa kevalidan data dalam penelitian ini, peneliti menggunakan cara apakah hasil wawancara yang telah dilakukan sesuai dengan hasil observasi yang peneliti lakukan.

\section{Hasil Penelitian}

\section{Pelaksanaan Wakaf Produktif}

Pelaksanaan Wakaf Produktif di Bank Wakaf Mikro syariah Dennyar Jombang, sistem penyaluran dana wakaf di Bank Wakaf Mikro dilaksanakannya dengan produktif dan disalurkannya kepada nasabah yang membutuhkan yang mempunyai usaha untuk mengembangkan usahanya, dengan menggunakan sysitem Kelompok Usaha Masyarakat Sekitar Pesantren Indonesia (KUMPI). Setiap kelompok ada 15 orang dan sistem pembayarannya perkelompok satu orang membiayai 1 juta dalam setiap penyaluran. Dalam sistem pembayarannya mengangsur setiap minggu dengan mengadakan Halaqoh Mingguan.

Pelaksanaan wakaf produktif itu ada tiga macan diantaranya adalah; pertama integrasi pola manajemen, kedua kesejahteraan nadzir, ketiga teransparansi dan accountable. Bank Wakaf Mikro Syariah Denanyar Jombang menerapkan dua filosofi yaitu integrasi pola manajemen dan kesejahteraan nadzir.

Dalam hal pelaporan keungan (transparansi) Bank Wakaf Mikro Syariah Denanyar Jombang hanya kepada orang tertentu yang mengetahuinya, maka dari itu Bank Wakaf Mikro Syariah Denanyar Jombang seharusnya dalam filosofi pelaksanaan wakaf produktif harus transparan kepada semua pihak bukan hanya kepada pihak tertentu.

Filosofi yang pertama integrasi pola manajemen di Bank Wakaf Mikro Syariah Denanyar Jombang konsep pola manajemennya sebagai berikut yang dilakukan Bank Wakaf Mikro Syariah Denanyar Jombang melakukan pencarian nasabah kemudian memeberikan arahan kepada nasabah yang mana nantinya nasabah akan memiliki usaha dari uang wakaf, contohnya adalah Bank Wakaf Mikro Syariah Denanyar Jombang mencari lima belas nasabah kemudian dijadikan tiga kelompok jadi setiap kelompok terdiri dari lima orang dari setiap kelompok salah satu dari kelompok dijadikan ketua 
Maulana Assegaf. Pelaksanaan Wakaf Produktif Di Bank Wakaf Mikro...

untuk memberikan arahan kepada anggotanya. Bank Wakaf Mikro Syariah Denanyar Jombang ini lembaga yang terlepas dari segala orientasi keuntungan ekonomi yang didedikasikan penuh untuk kesejahteraan sosial yaitu dengan memberikan pembiayaan bagi usaha kecil serta berfokus pada pembangunan ekonomi masyarakat marjinal. Bank Wakaf Mikro ini juga merupakan komitmen besar OJK bersama Pemerintah untuk terus memperluas penyediaan akses keuangan masyarakat, khususnya bagi masyarakat menengah dan kecil.

Sedangkan yang kedua kesejahteraan nadzir di Bank Wakaf Mikro Syariah Denanyar Jombang bahwasanya pihak penerima harta wakaaf dari waqif untuk dikelola serta dikembangkan sesuai dengan peruntukannya, Bank Wakaf Mikro Syariah Denanyar Jombang dalam mengelola uang wakaf dengan cara meminjamkan uang wakaf tersebut kepada nashabah, jadi seorang nshabah disini juga berperan sebgai nadzir karna ikut serta dalam mengelola uang wakaf, contohnya adalah uang wakaf tersebut dipinjamkan kepada nashabah sebesar RP 1.000.000 untuk dijadikan modal usaha atau untuk mengembangkan usaha nashabah yang telah memiliki usaha tersebut, sedangkan Bank Wakaf Mikro Syariah Denanyar Jombang memberikan pengawasan dan arahan terhadap nashabah yang mengelola usahanya dengan uang wakaf.

Dalam bentuk skema pembiayaan melalui Bank Wakaf Mikro pembiayaan tanpa agunan/jaminan dengan nilai maksimal Rp3 juta dan margin bagi hasil setara 3\%. Selain itu, dalam skema pembiayaan Bank Wakaf Mikro juga disediakan pelatihan dan pendampingan serta pola pembiayaan yang dibuat per kelompok atau tanggung renteng. Lembaga ini tidak diperkenankan mengambil simpanan dari masyarakat karena memiliki fokus pemberdayaan masyarakat melalui pembiayaan disertai pendampingan usaha. Lembaga ini juga berstatus sebagai Lembaga Keuangan Mikro Syariah yang diberi izin dan diawasi oleh OJK.

Mengingat potensi wakaf uang di Indonesia yang cukup besar, pemerintah kita telah mulai mengakomodir upaya pengembangan wakaf uang ini dengan diaturnya kebolehan penerapan wakaf uang dalam Undang-Undang Nomor 41 Tahun 2004 dan Peraturan Pemerintah Nomor 42 Tahun 2006. Model bank wakaf yang kami maksud disini adalah masih dalam tataran konsep yang akan diulas lebih lanjut. Menurut Pasal 1 Undang-Undang Nomor 10 Tahun 1998 tentang Perubahan atas Undang- 
Undang Nomor 7 Tahun 1992 tentang Perbankan, bank memiliki pengertian sebagai badan usaha yg menghimpun dana dari masyarakat dalam bentuk simpanan dan menyalurkannya kepada masyarakat dalam bentuk kredit dan atau bentuk-bentuk lainnya dalam rangka meningkatkan taraf hidup rakyat banyak.

Bank adalah sebuah lembaga yang bertujuan untuk meningkatkan taraf hidup rakyat banyak. Walaupun tidak bisa dipungkiri bahwa bank juga sebuah lembaga yang profit oriented atau berorientasikan pada profit ekonomis. Hal inilah yang berbeda dengan pengertian bank wakaf yang sepenuhnya bertujuan untuk meningkatkan kesejahteraan umat Islam dan juga masyarakat secara luas.

\section{Manajemen Pengelolaan}

Manajamen pengelolaan harta wakaf, pegawai dari Bank wakaf Mikro telah melakukan pengelolaan harta wakaf produktif, dalam pengelolaan wakaf produktif melakukan perencanaan, pengorganisasian, pengarahan, dan pengawasan, supaya pengelolaan uang wakaf bisa produktif.

Manajemen dalam perwakafan sangat diperlukan untuk mengatur atau mengontrol pengelolaan harta wakaf, dan untuk menjaga hubungan antara nazir, waqif, serta masyarakat. Supaya kesemuanya dapat berjalan dengan baik, maka seorang nadzir sebagai orang yang bertanggung jawab dalam mengurus, mengelola, dan mengembangkan harta wakaf harus dapat menguasai prinsip-prinsip manajemen yang meliputi; yang pertama tahap fungsi manajemen. Yang kedua manajemen fundraising, yang ketiga manajemen pengembangan, yang keempat manajemen pemanfaatan, yang kelima manajemen pelaporan.

Bank Wakaf Mikro Syariah Denanyar Jombang dalam manajamen pengelolaan harta wakaf, pegawai dari Bank waka melakukan pengelolaan harta wakaf supaya dapat berjalan dengan baik dengan meliputi prinsipprinsip manajemen pemanfaatan yaitu:

Yang pertama Tahap fungsi Manajemen, dari tahap fungsi manajemen BankWakaf Mikro Syariah Denanyar Jombang dalam pengelolaan wakaf produktif melakukan beberapa aspek manajemen yang dilakukan, yaitu perencanaan, pengorganisasian, pengarahan, dan pengawasan, ini dilakukan dalam pengelolaan supaya uang wakaf bisa produktif dan manfaat bagi masyarat sekitar pesantren. 
Maulana Assegaf. Pelaksanaan Wakaf Produktif Di Bank Wakaf Mikro...

Yang kedua Manajemen Fundraising. BankWakaf Mikro Syariah Denanyar Jombang dalam manajemen fundraising melakukan penyusunan strategi dan rencana program kerja dalam wakaf produktif, contohnya dalam penyusunan strategi BankWakaf Mikro Syariah Denanyar Jombang menata dengan terprinci dengan perumusan yang spesifik, sedangkan rencana program, contohnya BankWakaf Mikro Syariah Denanyar Jombang rencana program melakukan pembentukan kelompok, kelompok usaha masyarakat sekitar Pesantren Indonesia (KUMPI), sosialisasi konsep KUMPI kepada kelompok sasaran, uji kelayakan kelompok sasaran calon anggota KUMPI, pra pelatihan wajib kelompok (Pra PWK), pelatihan wajib kelompok (PWK), halaqoh mingguan (Halmi).

Yang ketiga Manajemen pengembangan. BankWakaf Mikro Syariah Denanyar Jombang dalam pengembangan uang wakaf menjadi sebuah alternatif dengan nashabah untuk mengembangkan uang wakaf menjadi sebuah uang wakaf yang produktif dan manfaat bagi masyarakat sekitar pesantren mambaul maarif. pengembangan strategi yang dilakukan BankWakaf Mikro Syariah Denanyar Jombang dalam pendanaan wakaf secara tradisonal, contohnya yaitu dengan meminjamkan uang wakaf, dengan pembayaran cash, dan pembayaran berkala.

Yang keempat manajemen pemanfaatan. Pendistribusian menurut sistem ekonomi Islam berdasarkan pada dua sendi yaitu, kebebasan dalam bertindak sesuai dengan nilai-nilai agama, serta keadilan dalam kepemilikan. BankWakaf Mikro Syariah Denanyar Jombang pemanfaatan uang wakaf di BankWakaf Mikro sebuah lembaga yang bertujuan untuk meningkatkan taraf hidup rakyat banyak. Walaupun tidak bisa dipungkiri bahwa bank juga sebuah lembaga yang profit oriented atau berorientasikan pada profit ekonomis. Hal inilah yang berbeda dengan pengertian bank wakaf yang sepenuhnya bertujuan untuk meningkatkan kesejahteraan umat Islam dan juga masyarakat secara luas.

Yang kelima manajemen pelaporan. Laporan keuangan merupakan refleksi dari beberapa transaksi dalam perusahaan. Bank Wakaf Mikro Syariah Denanyar Jombang pelaporan keuangannya disetiap pengeluaran dan pemasukan dilakukan penulisan dan pengecekan ulang untuk laorankeungan.

Jadi Karakteristik Bank Wakaf Mikro adalah pendampingan dan pengawalan. Ada seleksi sebelum nasabah melakukan pembiayaan. 
Targetnya masyarakat bawah yang mempunyai semangat dan kemauan tinggi. Penyaluran pembiayaan dilakukan melalui pesantren dengan proyeksi satu Lembaga Keuangan Mikro Syariah (LKMS) butuh sekitar 4-5 milyar.

Dari analisis ini akan mengulas sedikit tentang penerapan tanggung renteng yang di lakukan oleh masyarakat sekitar Bank Wakaf Mikro Syariah Denanyar Jombang dalam melakukan pembayaran angsuran atau yang biasa di sebut istilah Halmi (Halaqoh Mingguan) yang di lakukan antara kedua belah pihak setiap minggu atau 4 kali dalam satu.

Pelalatihan wajib kelompok (PWK) ini dilaksanakan 5 (lima) hari berturut-turut selama 1 jam tiap harinya pada waktu dan tempat yang sama setiap harinya. Waktu dan tempat berdasarkan pada kesepakatan anggota kelompok, Materi pelaksanaan PWK adalah,

Materi hari pertama, penjelasan PWK, pengenalan lembaga, pengenalan KUMPI, perkenalan peserta PWK, pengenalan dan penjelasan makna ikrar, penjelasan prinsip anggota KUMPI, tekad mengubah cara hidup. Materi hari kedua, pembacaan ikrar, memperbaiki niat usaha, disiplin, persahabatan, kerja keras dan kerja cerdas, hak dan kewajiban anggota, pemilihan ketua dan wakil ketua kelompok, pembahasan tanggung jawab ketua sekretaris dan anggota kelompok.

Materi hari Ketiga, pembacaan ikrar, prosedur pembiayaan, cara pembayaran angsuran, pengenalan akad, cerita profil usaha, cara pembuatan profil usaha. Materi hari Keempat, pembacaan ikrar, pemberian nama dan nomor kelompok, pemilihan ketua, wakil ketua Halmi, pembahasan tanggung jawab ketua, wakil ketua dan anggota Halaqoh mingguan, penetapan waktu Halmi. Materi hari Kelima, pembacaan ikrar, ujian pengesahan KUMPI.

\section{Kesimpulan}

Berdasarkan hasil penelitian dan hasil pembahasan, maka dapat ditarik beberapa kesimpulan penelitian sebagai berikut:

1. Proses Pelaksanaan Wakaf Produktif di Bank Wakaf Mikro Syariah Denanyar Jombang, uang wakaf tersebut modal awalnya dari hasil penyumbang yng mana disalurkan kepada yang membutuhkan, sistem penyalurannya dengan produktif, dan disalurkannya kepada nasabah yang membutuhkan yang mempunyai usaha untuk mengembangkan 
Maulana Assegaf. Pelaksanaan Wakaf Produktif Di Bank Wakaf Mikro...

usahanya, cara penyalurannya itu dengan sysitem Kelompok Usaha Masyarakat Sekitar Pesantren Indonesia (KUMPI). Setiap kelompok ada 15 orang dan sistem pembayarannya perkelompok satu orang membiayai 1 juta dalam setiap penyaluran. Dalam sistem pembayarannya mengangsur setiap minggu dengan mengadakan Halaqoh Mingguan (HALMI) dalam bentuk komunikasi dari pihak PWM dengan Nasabah untuk komunikasi mengembangkan usah Nasabah.

2. Bank Wakaf Mikro Syariah Denanyar Jombang dalam manajamen pengelolaan harta wakaf, pegawai dari Bank wakaf telah melakukan pengelolaan harta wakaf produktif supaya dapat berjalan dengan baik, dalam pengelolaan wakaf produktif melakukan perencanaan, pengorganisasian, pengarahan, dan pengawasan, ini dilakukan dalam pengelolaan supaya uang wakaf bisa produktif dan manfaat bagi masyarat sekitar pesantren. Adapun cara dalam merekrut nashabah di Bank Wakaf Mikro ini menggunakan Prinsip tanggung renteng yang di uraikan sebagai berikut: Pemberdayaan Masyarakat Miskin, Pendampingan sesuai prinsip syariah, Ta'awun, Sahl, Amanah, Keberlanjutan Program, Keberkahan.

\section{Daftar Pustaka}

Departemen Agama, Perkembangan Pengegeloaan Wakaf di Indonesia (Jakarta: Direktorat Jenderal Bimbingan Masyarakat Islam dan Penyelenggaraan Haji, 2003).

Furqon, Ahmad. "Model-Model Pembiayaan Wakaf Tanah Produktif". ECONOMICA, V (1) 2014.

Hadi, Abu Azam. "Upaya Pemberdayaan Tanah Wakaf Produktif bagi Kesejahteraan Ummat". ISLAMICA, 4 (1) 2009.

Hermawan, Wawan. "Politik Hukum Wakaf di Indonesia”. Ta'lim: Jurnal Pendidikan Islam, 12 (2) 2014.

Munir, Akhmad Sirojudin. "Optimalisasi Pemberdayaan Wakaf Secara Produktif". Jurnal Ummul Qura, IV (2) 2015.

Rahman, Asmak Ab. "Peranan Wakaf dalam Pembangunan Ekonomi Umat Islam dan Aplikasinya di Malaysia". Jurnal Syairiah, 17 (1) 2009. 
MAZAWA: Manajement of Zakah and Waqf

Volume 1, Nomor 1 Desember 2019

Sa'adah, Nailis., Fariq Wahyudi, "Manajemen Wakaf Produktif : Studi Analisis pada Baitul Mal di Kabupaten Kudus". Equilibrium : Jurnal Ekonomi Syari'ah Vol 4, Nomor 2, 2016.

Sabri, Fahruddin Ali. "Wakaf Uang (Sebuah Alternatif dalam Upaya Menejahterakan Masyarakat)". Al-Ihkam, 8 (1) 2013.

Sugiyono, Metodologi Penelitian Kuantitatif, Kualitatif dan RED, (Bandung: Alfabeta, 2013). 
MAZAWA: Manajement of Zakah and Waqf

Volume 1, Nomor 1 Desember 2019 